\title{
COPING STRES PADA ORANG TUA ANAK DENGAN LEUKEMIA LIMFOSITIK AKUT(ALL)
}

\author{
Desi Lustiyani Wahono ${ }^{1}$ \\ Shanty Sudarji ${ }^{2}$ \\ Program Studi Psikologi Universitas Bunda Mulia \\ gbu120711@gmail.com
}

\begin{abstract}
Cancer is not a contagious disease but can cause death, especially in children. Cancer that primarily affects children is leukemia with the number of about 25 to $30 \%$ of all types of cancer that affects all children in Indonesia. Common type of leukemia in children is acute lymphocytic or lymphoblastic leukemia (ALL) with a percentage of $82 \%$ and acute myelocytic leukemia (AML) by $18 \%$. The role of parents in caring for sick children ALL is not easy, a lot of problems that will occur during the care of children who ALL, either of themselves, their families and the environment. Coping with stress is necessary to handle problems that occur during the care for ALL children. Researchers conducted qualitative research with interviews of five parents who have children with acute lymphocytic leukemia. The data obtained showed that the main source of stress experienced came from a family that is the condition of a sick child, then the source of the stress from the environment and self. Symptoms of stress experienced by the whole subject is prolonged fear and sadness. The whole subject $S, R S, M E, D M$, and NP using problem focused coping that are planful problem solving, seeking social support and coping confrontative. All subjects also use emotion focused coping. The whole subject of $S, R S, M E, D M$, and NP using self control, accepting responsibility, and positive reappraisal. Only the subject of RS, ME, NP which uses distancing.
\end{abstract}

Keywords: coping stress; acute lymphocytic leukemia; parents

\begin{abstract}
ABSTRAK
Penyakit kanker bukan penyakit menular namun dapat menyebabkan kematian terutama pada anak-anak. Penyakit kanker yang umumnya menyerang anak-anak adalah leukemia dengan jumlah penderita sekitar 25 sampai 30\% dari seluruh jenis kanker yang diderita semua anak di Indonesia. Tipe leukemia yang sering terjadi pada anak-anak adalah acute lymphocytic leukemia or lymphoblastic (ALL) dengan persentase sebesar $82 \%$ dan acute myelocytic leukemia (AML) sebesar 18\%. Peran orang tua dalam merawat anak yang sakit ALL tidaklah mudah, banyak sekali masalah yang akan terjadi selama merawat anak yang ALL, baik dari diri sendiri, keluarga dan lingkungan. Coping stres sangat diperlukan untuk menangani masalah yang terjadi selama merawat anak yang ALL. Peneliti melakukan penelitian kualitatif dengan wawancara kepada 5 orang tua yang memiliki anak leukemia limfositik akut. Data menunjukan bahwa sumber stres utama yang dialami berasal dari keluarga yakni kondisi anak yang sakit, kemudian sumber stres dari lingkungan dan diri sendiri. Gejala stres yang dialami seluruh subjek adalah ketakutan dan sedih berkepanjangan. Seluruh subjek S, RS, ME, DM, dan NP menggunakkan problem focused coping antara lain planful problem solving, seeking social support dan confrontative coping. Seluruh subjek juga menggunakan emotion focused coping. Seluruh subjek S, RS, ME, DM, dan NP menggunakkan self control, accepting responsibility, dan positive reappraisal. Hanya subjek RS, ME, NP yang menggunakan distancing
\end{abstract}

Kata Kunci: coping stress, leukemia limfositik akut; orang tua 


\section{PENDAHULUAN}

\subsection{Latar Belakang}

Penyakit kanker adalah penyakit yang menakutkan bagi setiap orang, penyakit ini bukanlah penyakit menular namun menyebabkan kematian yang tidak sedikit khususnya pada anak-anak (Simanjorang, dkk 2013). Menurut Data Organisasi Kesehatan Dunia (WHO) tahun 2012, menyatakan bahwa setiap tahun penderita kanker di dunia bertambah 6,25 juta orang, dan dari jumlah tersebut sebesar $4 \%$ atau 250.000 penderitanya adalah anak-anak. Kanker yang umumnya menyerang anak-anak adalah leukemia dengan penderita sekitar 25 sampai 30\% dari seluruh jenis kanker yang diderita semua anak di Indonesia.Tipe leukemia yang sering terjadi pada anak-anak adalah acute lymphocytic leukemia or lymphoblastic (ALL) dengan persentase sebesar $82 \%$ dan acute myelocytic leukemia (AML) sebesar 18\% (Pinontoan, dkk, 2013).

Leukemia adalah jenis penyakit yang menyerang sel darah putih yang diproduksi oleh sumsum tulang. Pada penyakit leukemia, sel darah putih tidak merespon pada tanda yang diberikan, akhirnya produksi sel darah putih menjadi tidak terkontrol atau abnormal (Ugrahsena, 2012). Leukemia memiliki beberapa tipe didasarkan dari kecepatan laju penyakitnya yaitu leukemia akut dan leukemia kronis (Sheridan, dkk, 1992 dalam Rizkiana, 2012). Menurut salah satu praktisi di Yayasan Onkologi Anak Indonesia atau YOAI, Kartika Purwanto, pengobatan penyakit leukemia baik pada anak maupun orang dewasa memakan waktu yang panjang, minimal dua tahun, lalu anak bisa dikatakan sembuh jika sudah melewati lima tahun (Wulandari, 2014).

Diagnosa kanker pada anak adalah pengalaman yang traumatik, karena kanker sendiri menghasilkan rasa sakit yang signifikan, ancaman terhadap tubuh sendiri dan kemungkinan akan kematian (Meister, dkk, 1993 dalam Boyer, dkk, 2009). Kaget, sedih dan bingung adalah respon yang dimunculkan orang tua pasien leukemia saat pertama kali anaknya terdiagnosis leukemia (Aziz, dkk, 2005). Seperti yang dialami oleh ibu DC, orang tua dari anak yang terdiagnosa ALL, ketika anaknya di diagnosa dokter terkena leukemia limfositik akut.

"mending mati saya, sayanya, jangan anak saya. Saya udah gak bisa berpikir, udah kaya meledak kepala saya.langsung nangis"
Hal ini diikuti oleh pengobatan yang sifatnya invasif, resiko untuk relaps, dan kemungkinan efek samping yang akan terjadi di kemudian hari (Meister, dkk, 1993 dalam Boyer, dkk, 2009). Pasien yang mengalami penyakit kronis seperti leukemia akan mengalami ketergantungan pada keluarga akibat dari keterbatasan dan ketidakmampuan sebagai respon dari rasa sakit dan trauma (Mussatto, 2006 dalam Cahyono, 2012), terutama kepada orang tua. Hal yang mejadi stres orang tua dalam merawat anak leukemia adalah membantu si anak untuk melalui beberapa tes medis, prosedur dan perubahan medis, juga membantu mereka untuk memahami situasi yang sedang mereka jalani ini (Stern, dkk, 2004), selain itu masalahmasalah akibat penyakit leukemia limfositik akut yang dapat memicu stres yaitu pengobatan yang cukup lama (kurang lebih 2 tahun), biaya pengobatan yang tergolong mahal, dan bisa menyebabkan kematian pada anak (Rani, dkk, 2015). Untuk menangani stres dalam merawat anak yang sakit leukemia limfositik akut, orang tua perlu melakukan usaha coping.

Usaha coping sendiri bertujuan untuk membuat keadaan yang tidak menguntungkan menjadi lebih menguntungkan (Kovacs, 2007 dalam Gilmartin, 2009). Lazarus dan Folkman (1984) mengidentifikasikan 2 dimensi dari coping, pertama problem focused coping dan emotion focused coping baik problem focused coping dan emotion focused coping akan lebih efektif dilakukan bila sesuai dengan situasi dan kondisi yang sedang berlangsung (Kring, dkk, 2010).

Berdasarkan wawancara dengan lima orang tua anak penderita ALL didapatkan informasi bahwa permasalahan yang menimbulkan stres bagi orang tua adalah diagnosa awal dari dokter bahwa anak mereka terkena ALL. Kemudian orang tua juga harus mengorbankan pekerjaan bahkan sampai menitipkan anak kepada nenek atau kakeknya, beberapa terpaksa memberhentikan pendidikan anak lainnya karena biaya pendidikan sudah dialokasikan untuk pengobataan anak yang ALL dan perhatian orang tua fokus kepada anak yang sakit. Di samping itu, orang tua harus menyesuaikan diri dengan kehidupan yang berubah, seperti membiasakan diri menyaksikan anak menjalani perawatan medis, beradaptasi dengan perubahan mood anak, lebih perhatian dalam mengurus apa yang 
diizinkan dan tidak diizinkan untuk di konsumsi anak ALL, menjaga anak agar tidak terbentur atau terluka, dan harus membuat anak tetap senang dan semangat selama menjalani pengobatan.

Selain itu minimnya informasi yang diterima juga menimbulkan stres bagi orang tua. Orang tua menyampaikan bahwa mereka mendapatkan informasi umum seputar merawat anak dari tenaga medis, namun informasi yang dijelaskan dianggap kurang detil terutama istilah-istilah medis yang biasa dipakai dalam merawat anak ALL seperti BMP (Bone Marrow Punction), SGPT (Serum Glutamic Pyruvate Transaminase), dan SGOT (Serum Glutamic Oxaloacetic Transaminase) sehingga orang tua tidak tahu penanganan yang harus diberikan. Sulitnya mencari obat dan darah untuk transfusi juga menimbulkan stres pada orang tua, kesulitan ini dialami apabila pengobatan dengan menggunakan BPJS. Menurut pengakuan orang tua, pasien kanker yang menjalani pengobatan dengan BPJS kurang diprioritaskan. Jika rumah sakit tempat anak rawat inap tidak memiliki persediaan darah dan obat oral, orang tua harus berkeliling ke rumah sakit lain mencari ketersediaan darah maupun obat.

Proses coping yang dijalani setiap orang tua pun berbeda-beda. Seperti orang tua yang selama merawat anak lebih banyak marah baik kepada anak dan orang-orang disekitarnya, lalu orang tua yang menyalahkan Tuhan namun tetap berdoa untuk memohon kesembuhan anaknya. Selain itu orang tua yang tidak berhenti mengaji dan memohon pada yang Maha Kuasa, juga orang tua yang mengintropeksi dirinya sendiri sambil bertanya-tanya apakah ia melakukan kesalahan selama ia hidup sehingga anaknya mengalami ALL, dan orang tua yang proaktif mencari informasi, bertukar dan berbagi dengan sesama orang tua penderita ALL. Seluruh orang tua mengaku mereka berusaha sebaik mungkin mengontrol perasaan atau emosi mereka, walaupun mereka sedih, mereka tidak menunjukkannya di depan orang lain terutama anak mereka.Berdasarkan latar belakang di atas, penulis tertarik untuk melakukan penelitian ini dengan tujuan mengetahuinya coping stres pada orang tua anak penderita leukemia limfositik akut.

\subsection{Tujuan Penelitian}

Penelitian ini bertujuan untuk mengetahui gambaran coping stress pada orang tua anak dengan Limfositik Akut (ALL).

\section{TINJAUAN PUSTAKA \\ 2.1. Definisi Stres}

Menurut APA Dictionary of Psychology (2007), stres adalah respon fisiologis atau psikologis pada internal atau eksternal stressor. Stres berdampak pada perubahan hampir disetiap sistem dalam tubuh, mempengaruhi bagaimana orang merasa dan berpikir.

\subsection{Sumber Stres}

Menurut Sarafino (2012), sumber stres manusia berasal dari tiga hal yaitu:

a. Sumber stres berasal dari diri sendiri Salah satu penyebab stres biasanya adalah penyakit yang diderita individu. Sakit dapat mempengaruhi sistem biologi dan psikologis, derajat stres individu dipengaruhi dari seberapa besar sakit yang diderita dan usia orang tersebut. Selain itu stres yang muncul dari diri sendiri adalah ketika adanya perlawanan saat konflik berlangsung.

b. Sumber stres dari keluarga

Keluarga dapat menjadi tempat yang paling nyaman, namun juga dapat menjadi sumber stres. Hal yang umumnya dapat menjadi stressor adalah adanya anggota keluarga baru, konflik pernikahan dan perceraian, dan sakit atau kematian pada anggota keluarga.

c. Sumber stres dari komunitas dan masyarakat

Berhubungan dengan orang lain diluar keluarga dapat menimbulkan stres. Pekerjaan dan lingkungan juga dapat menjadi sumber stres bagi seseorang.

\subsection{Gejala Stres}

Menurut Terry Beehr dan John Newman (Taylor, 2006 dalam Rustiana, dkk, 2012), gejala stres dibagi dalam tiga aspek yaitu :

a. Gejala psikologis

Meliputi kecemasan, tegang, bingung, marah, sensitif, memendam perasaan, komunikasi tidak efektif, mengurung diri, depresi, merasa terasing dan 
mengasingkan diri, kebosanan, ketidakpuasan kerja, lelah secara mental, menurunnya fungsi intelektual, kehilangan konsentrasi, kehilangan spontanitas dan kreativitas, kehilangan semangat hidup, menurunnya rasa percaya diri dan keberhagaan diri.

b. Gejala fisik

Meliputi meningkatnya detak jantung dan tekanan darah, meningkatnya sekresi adrenalin dan nonadrenalin, gangguan gastrointestinal (misalnya gangguan lambung), mudah terluka, mudah lelah secara fisik, kematian, gangguan pada kulit, gangguan kardiovaskuler, gangguan pernafasan, sering berkeringat, kepala pusing, migrain, ketegangan otot, masalah tidur (sulit tidur, terlalu banyak tidur).

c. Gejala perilaku

Meliputi menunda atau menghindari pekerjaan, penurunan prestasi dan produktivitas, meningkatnya penggunaan minuman keras dan mabuk-mabukan, perilaku sabotase, meningkatnya frekuensi absen (misalnya di kantor), perilaku makan yang tidak normal (kebanyakan atau kekurangan), kehilangan nafsu makan dan penurunan berat badan secara drastis, meningkatnya kecenderungan perilaku berisiko tinggi (seperti kebutkebutan \& berjudi), meningkatnya agresivitas dan kriminalitas, penurunan kualitas hubungan interpersonal dengan keluarga dan teman dan kecenderungan untuk bunuh diri.

\subsection{Coping stres}

Menurut APA Dictionary of Psychology (2007), coping adalah menggunakan strategi kognitif dan perilaku untuk mengatasi situasi ketika situasi tersebut dinilai berat atau melebihi kemampuan seseorang atau mengurangi emosi negatif dan konflik yang timbul karena stres. Coping juga di definisikan sebagai strategi yang digunakan individu untuk mengelola masalah menyedihkan dan emosi dalam hidup mereka (Brannon, dkk, 2014).
Taylor (2006) mengkategorikan strategi coping menjadi dua yaitu problem-focused coping dan emotion-focused coping.

Problem-focused coping, meliputi:

a. Planful Problem Solving dikarakteristikkan dengan usaha menyelesaikan masalah dengan tenang untuk memperbaiki situasi dengan pendekatan analitis atau menyusun rencana.

b. Seeking Social Support dikarakteristikan dengan mencari informasi, dukungan dan kenyamanan dari orang lain.

c. Confrontative Coping dikarakteristikkan dengan tindakan agresif untuk merubah situasi.

Emotion-focused coping, meliputi:

a) Distancing adalah usaha yang dilakukan untuk menjauhkan diri dari situasi yang penuh tekanan.

b) Self Control usaha untuk mengontrol perasaan atau tindakkan yang dilakukan.

c) Accepting Responsibility adalah mengakui peran diri sendiri dalam masalah yang dihadapi.

d) Escape Avoidance adalah menghindari masalah dengan berandai-andai atau usaha untuk lari dari masalah atau situasi dengan dialihkan kepada kegiatan lain, seperti makan, rokok, minum-minuman keras, memakai narkoba, atau mengkonsumsi obat terlarang.

e) Positive Reappraisal adalah mencari makna positif dari pengalaman yang dihadapi dan fokus pada pengembangan diri.

\subsection{Anak dengan Leukemia Limfositik} Akut

Leukemia adalah prototipikal tumor cair, tidak seperti kanker paru-paru atau payudara, leukemia terletak di aliran darah dan umumnya sudah tersebar pada tubuh ketika orang didiagnosa. ALL muncul ketika mutasi dari batang sel limfoid mengakibatkan sel tidak matang membelah secara tidak terhingga dan tidak membentuk limfosit $\mathrm{B}$ dan $\mathrm{T}$. Batang sel kanker ini tidak memiliki fungsi, karena mereka belum terlalu matang untuk membasmi kuman. Jika terlalu lama, sel ini 
mampu mengambil seluruh tempat yang ada di sumsum tulang dan menggantikam hampir semua batang sel nonleukemia yang sehat. (Stern \& Sekeres, 2004)

\section{METODE PENELITIAN}

Subyek dalam penelitian ini adalah orang tua yang memiliki anak terdiagnosa ALL. Karakteristik subjek untuk penelitian ini adalah orang tua kandung (ibu atau ayah) dari anak penderita leukemia limfositik akut, berusia di bawah 15 tahun yang anaknya masih menjalani pengobatan medis. Selain itu orang tua yang akan berpartisipasi dalam penelitian ini merawat sendiri anaknya yang sakit. Sebelum penelitian dilaksanakan, peneliti sudah melakukan rapport building kemudian meminta kesediaan subyek untuk mengikuti wawancara. Berdasarkan kriteriakriteria di atas, subyek yang terlibat dalam penelitian ini berjumlah lima orang, dengan perincian sebagai berikut:

Tabel 1: Subyek Penelitian

\begin{tabular}{lll}
\hline Inisial & \multicolumn{1}{c}{ Usia } & \multicolumn{1}{c}{$\begin{array}{c}\text { Jenis } \\
\text { Kelamin }\end{array}$} \\
\hline $\mathrm{S}$ & 35 tahun & Perempuan \\
$\mathrm{RS}$ & 33 tahun & Perempuan \\
$\mathrm{ME}$ & 32 tahun & Perempuan \\
$\mathrm{DM}$ & 31 tahun & Laki-laki \\
$\mathrm{NP}$ & 36 tahun & Perempuan \\
\hline
\end{tabular}

Penelitian ini terdiri dari dua tahap yaitu tahap persiapan dimana pada tahap ini peneliti mempersiapkan panduan wawancara yang sesuai dengan penelitian ini, wawancara yang dilakukan adalah wawancara terstruktur. Kemudian peneliti juga menyiapkan peralatan yang diperlukan untuk wawancara seperti kamera, alat perekam, informed consent dan alat tulis. Setelah tahap persiapan selesai, peneliti melanjutkan ke tahap pelaksanaan, pada tahap ini peneliti langsung menemui subjek untuk melakukan wawancara dan observasi secara bersamaan.

\section{HASIL DAN PEMBAHASAN}

Diketahui yang menjadi sumber stres utama berasal dari keluarga yaitu diagnosa awal anak dan sakit yang diderita oleh anak sendiri, kemudian sumber stres yang kedua datang dari lingkungan sekitar orang tua seperti teman dekat dan pihak rumah sakit. Sumber stres yang ketiga berasal dari diri sendiri baik dari rasa tidak berdaya karena tidak bekerja dan sakit yang diderita oleh orang tua sehingga menghambat dalam merawat anaknya yang ALL.

Menurut seluruh subjek, sumber stres utama adalah gejala yang ditunjukkan anak sebelum sakit dan diagnosa ALL pada anak. Subjek RS, ME dan NP mengalami kesulitan membagi perhatian dan waktu dengan anak yang sehat, $\mathrm{S}$ dan RS mengalami kesulitan dalam biaya perjalanan untuk ke rumah sakit, ME dan NP merasa sangat terganggu dengan perubahan sikap dan perilaku anaknya sedangkan $\mathrm{S}$ mengalami masalah perceraian dengan suaminya dan anak keduanya meninggal dunia karena sakit. Sumber stres dari lingkungan yang dirasakan oleh $\mathrm{ME}$ adalah tertekan dengan pertanyaan dari temanteman kantor yang seakan menyudutkannya, kemudian pada DM harus mengalami penundaan pengobatan padahal kondisi anaknya semakin memburuk, NP merasa terganggu dengan perkataan dokter yang meminta untuk bersiap-siap kehilangan anaknya saat ananya kritis dan drop. Kemudian sumber stres yang terakhir berasal dari diri sendiri, dialami DM yang merasa tidak bertanggung jawab atas keluarganya karena tidak mencari nafkah, dan pada NP, ia memiliki sakit diabetes yang membuatnya tidak boleh terlalu lelah.

Gejala stres yang dialami oleh ke lima subjek mempengaruhi baik fisik, psikologis dan perilaku. Gejala stres paling dominan adalah yang mempengaruhi psikologis yaitu timbulnya pikiran negatif mengenai kondisi anak mereka dan timbulnya kesedihan yang berkepanjangan, $\mathrm{S}$ dan DM mengalami kejenuhan karena menjalani rutinitas merawat anak, S merasa sangat uring-uringan semenjak anaknya sakit, RS mengalami kelelahan secara pikiran, dan ME menjadi sering melamun. Gejala stres yang mempengaruhi fisik juga dialami oleh setiap subjek, yaitu kesulitan untuk tidur dan kelelahan secara fisik. Selain itu RS menjadi mudah sakit, dan NP mengalami peningkatan gula darah. Gejala stres yang mempengaruhi perilaku juga dialami setiap subjek, yaitu tidak memiliki selera makan sehingga pola makan tidak teratur dan mengalami penurunan berat badan, RS menjadi lebih sering menangis, $\mathrm{ME}$ menjadi jarang keluar rumah dan NP berubah yang tadinya periang menjadi lebih pendiam. 
Pada aspek problem focused coping seluruh subjek menggunakan planful problem solving, yaitu merencanakan pengobatan untuk anak mereka sesuai dengan prosedur medis. Pada ME, DM dan NP mereka merencanakan pendidikan untuk anaknya, DM dan NP ingin kembali ke tempat asalnya dan mengusahakan pola makan sehat untuk anak mereka, S, RS dan DM merencanakan keuangan, kemudian $\mathrm{S}$ bekerja untuk menghidupi anaknya. Seeking social support dilakukan seluruh subjek dengan mencari dukungan moril dan materil kepada keluarga mereka. Dukungan moril juga diperoleh dari teman-teman yang memiliki anak kanker di rumah sakit, biasanya hal yang dilakukan adalah sharing dan saling menguatkan satu sama lain. RS dan NP mencari dukungan dari tetangga. Pada ME, DM, dan NP ketiganya mencari informasi seputar penyakit anak kepada ahli seperti dokter, suster dan dengan bantuan internet. Confrontative coping dilakukan seluruh subjek dengan cara marah, seperti memukul, membentak dan menatap tajam ke arah anak. RS tidak berpikir panjang ketika tidak punya biaya untuk ke rumah sakit, RS akan membawa uang yang tersisa di kantongnya untuk tetap dapat pergi dan tidak memikirkan cara untuk pulang ke rumah walaupun uangnya sudah habis.

Pada aspek emotion focused coping, ke lima subjek menggunakan self control, accepting responsibility dan positive reappraisal, tiga subjek (RS, ME, NP) menggunakan distancing dan tidak ada subjek yang menggunakan escape avoidance, karena mereka tidak mau lepas tangan dari masalah yang dialami. Pada self control seluruh subjek dapat mengontrol emosinya dengan cara berdiam diri atau masuk ke kamar untuk menangis. Bentuk accepting responsibility yang dilakukan seluruh subjek adalah menerima dan memahami peran yang mereka jalani dalam masalah ini. Pada subjek $S$, ia berperan sebagai ayah dan ibu bagi anaknya karena setelah bercerai mantan suaminya tidak memberi nafkah sehingga $S$ lah yang mencari nafkah, ME dan NP menyadari peran mereka bertambah karena harus menjaga anak mereka lebih hati-hati daripada menjaga anak yang lainnya.

Bentuk positive reappraisal yang dilakukan seluruh subjek adalah menganggap masalah yang dihadapi ini adalah sebagai cobaan dari Tuhan. Seluruh subjek juga percaya mereka telah berusaha dan menyerahkan hasil usahanya kepada Tuhan, ME dan DM termotivasi berusaha karena melihat perkembangan kondisi anak mereka yang membaik, $\mathrm{S}$ menjadi lebih banyak berdoa dan berusaha untuk menjadi sehat agar mampu bekerja dan merawat anaknya, ME juga menjadi lebih kreatif karena ia harus mengembangkan strategi untuk merayu anaknya yang enggan minum obat dan memakai masker, DM ingin selalu berbagi kepada sesama jika Tuhan memberinya umur panjang dan rejeki, NP merasa masalah ini adalah sebagai tempatnya untuk belajar bersyukur. Coping distancing yang dilakukan RS menjauhi anaknya jika anaknya sedang mengamuk di rumah sakit dengan bersembunyi di belakang tembok, $\mathrm{ME}$ memisahkan ruang rawat inap anaknya dengan yang lain agar tidak mendengar kabar buruk tentang anak-anak yang meninggal karena penyakitnya dan NP menjauhkan diri dari anaknya jika merasa sudah tidak sanggup menghadapi perilaku anaknya.

Pada S, problem focused coping yang dilakukan antara lain planful problem solving, seeking social suppoert dan confrontative coping. Hal ini dibuktikan dengan fokus pada penyelesaian masalah yang dihadapi, seperti ketika pemasukkannya berhenti, merencanakan sesuatu untuk menunjang kehidupannya dengan bekerja. Kemudian S sering meminta bantuan kepada orang lain jika sedang membutuhkan dan $S$ juga akan memarahi anaknya jika anaknya nakal dan tidak patuh pada dirinya. Sementara emotion focused coping yang dilakukan oleh S antara lain self control, accepting responsibility, dan positive reappraisal dengan tidak mengekspresikan kemarahannya di depan A, lalu $\mathrm{S}$ juga menjadi ibu sekaligus ayah bagi anaknya dan dengan banyak berdoa kepada Tuhan dan berusaha tetap sehat.

Pada RS, strategi problem focused coping yang dilakukan antara lain planful problem solving, seeking social support dan confrontative coping. Hal ini dibuktikan RS yang merencanakan pengobatan medis, selalu mencari informasi kepada dokter, suster, dan teman-teman yang memiliki anak ALL seperti dirinya. RS sering meminta pertolongan kepada tetangga, jika tidak memiliki uang untuk biaya perjalanan anaknya ke rumah sakit dengan meminta tumpangan atau meminjam uang dari tetangganya. Selama menjalani 
perawatan RS sering memaksa anaknya untuk melakukan pengobatan jika anaknya menolak ke rumah sakit. Sementara emotion focused coping yang dilakukan oleh RS antara lain self control, accepting responsibility, distancing dan positive reappraisal. Hal ini dilakukan RS dengan tidak menangis di depan $\mathrm{S}$ takut $\mathrm{S}$ akan bertanya-tanya mengenai penyakitnya, menerima peran yang harus bertambah saat ini, RS juga menjauhkan diri dari $S$ jika $S$ megamuk dirumah sakit, dan yang terakhir RS berusaha semaksimal mungkin dan menyerahkan hasil dari usahanya kepada Tuhan.

Pada ME, strategi problem focused coping yang dilakukan antara lain planful problem solving, seeking social support dan confrontative coping. Hal ini dilakukan ME dengan melakukan perencanaan pengobatan juga pendidikan untuk anaknya, kemudian ME juga tidak segan meminta bantuan kepada keluarga jika mengalami hambatan dalam membagi waktu menjaga anak dan bekerja, ME juga mencari informasi seputar penyakit yang diderita anaknya, dan ME juga tidak segan memarahi anaknya jika anaknya berbuat salah. Sementara pada emotion focused coping yang dilakukan oleh ME adalah self control, accepting responsibility, distancing dan positive reappraisal. Hal ini dibuktikan dengan ME lebih mengutamakan coping yang membuatnya lebih nyaman secara emosi, seperti memilih untuk memisahkan ruangan anaknya dengan ruangan anak lain agar ia tidak mendengar berita buruk tentang anakanak yang tidak mampu bertahan karena sakitnya.Selain itu ME juga menerima peran yang saat ini ia jalankan sebagai ibu rumah tangga yang bekerja dan merawat keluarga serta anaknya yang sakit ALL. ME juga percaya bahwa semua masalah yang terjadi dalam hidupnya ini sudah takdir dari Tuhan dan percaya Tuhan akan menyembuhkan anaknya.

Pada DM, strategi problem focused coping yang dilakukan antara lain planful problem solving, seeking social support dan confrontative coping. Hal ini dilakukan DM dengan merencanakan pengobatan untuk anaknya dan berencana untuk pulang kembali ke Lampung setelah $F$ menyelesaikan pengobatannya di Jakarta, DM juga mencari dukungan, bentuk dukungan yang diperoleh oleh DM adalah bentuk moril dan materil dari keluarag dan teman-temannya. Sementara pada emotion focused coping, DM melakukan self control, accepting responsibility, dan positive reappraisal. Hal ini dilakukan DM dengan mengontrol emosinya agar tidak meluap di depan anaknya, DM juga mampu menerima peran baru dalam masalah yang sedang dihadapi olehnya. Selain itu DM mengaku semakin dekat dengan Tuhan dan rajin beribadah, ia juga ingin selalu bersedekah jika diberikan umur panjang dan rejeki dari Tuhan, karena ia tahu rasanya kesusahan dan hidup bergantung dari bantuan orang lain.

Pada NP strategi problem focused coping yang dilakukan antara lain planful problem solving, seeking social support dan confrontative coping. Hal ini dilakukan NP dengan selalu mengikuti pengobatan yang direncanakan dokter. Ia juga selalu memperhatikan apapun yang dikonsumsi anaknya dan sebisa mungkin menjaga agar gula darahnya tidak kambuh, kemudian mencari informasi mengenai penyebab kanker yangbadru diderita anaknya kepada dokter dan tetangga dan marah atau memukul secara perlahan SA jika sudah tidak tahan dengan perilakunya. Sementara pada emotion focused coping, NP melakukan self control, accepting responsibility, distancing dan positive reappraisal. Hal ini dibuktikan dengan NP lebih mengutamakan coping yang membuatnya lebih nyaman secara emosi, seperti jika sudah sangat marah NP akan beribadah kepada Tuhan untuk menenangkan dirinya, NP juga meyakini bahwa masalah yang dihadapi ini adalah cobaan dari Tuhan entah untuk menaikkan derajatnya atau menebus dosa di masa lalu. NP juga ikhlas menerima masalah yang ia hadapi ini. Selain itu NP, juga menerima perannya yang harus bertambah karena merawat anak yang menderita ALL. Masalah ini juga membuat NP semakin bersyukur kepada Tuhan, karena ia melihat banyak orang lain yang mengalami masalah lebih berat dibanding dirinya.

Berdasarkan hasil wawancara dari kelima subjek diketahui bahwa strategi coping yang dilakukan berbeda-beda, hal ini terjadi karena terdapat faktor-faktor yang mempengaruhi individu dalam melakukan coping stres seperti (1) kesehatan fisik dimana seluruh subjek dituntut untuk mengerahkan tenaganya selama melakukan strategi coping, (2) keyakinan atau pandangan, seperti keyakinan akan nasib yang membuat individu enggan berusaha sehingga menurunkan 
kemampuan coping, (3) keterampilan memecahkan masalah meliputi kemampuan untuk mencari informasi, menganalisa situasi dan mengidentifikasi masalah untuk menghasilkan alternatif pemecahan masalah (4) keterampian sosial yang meliputi berbahasa dan bertingkah laku sesuai dengan nilai sosial di masyarakat, (5) dukungan sosial yang meliputi dukungan emosional dan informasi dari orang yang dikasihi, dan (6) faktor materi yang meliputi sumber daya uang dan barang (Mu'tadin dalam Andriyani, 2014).

Pada S strategi coping yang dilakukan dipengaruhi oleh faktor keterampilan memecahkan masalah meliputi kemampuan untuk mencari informasi, menganalisa situasi dan mengidentifikasi masalah untuk menghasilkan alternatif pemecahan masalah dan faktor materi yang meliputi sumber daya uang dan barang. $S$ mengetahui bahwa pemasukkannya berhenti dan ia sesegera mungkin mencari jalan keluar dengan bekerja di cafe malam untuk menghidupi dan meneruskan pengobatan anaknya.

Pada RS strategi coping yang dilakukan dipengaruhi oleh faktor kesehatan fisik di mana seluruh subjek dituntut untuk mengerahkan tenaganya selama melakukan strategi coping, dimana RS menjadi lebih mudah sakit karena menjalankan perannya saat ini. Kemudian keterampilan memecahkan masalah, keterampian sosial yang meliputi berbahasa dan bertingkah laku, dukungan sosial, dan faktor materi yang meliputi sumber daya uang dan barang. RS mengetahui ketika ia tak memiliki uang yang cukup untuk membawa anaknya berobat, ia meminjam uang kepada tetangga atau saudara. Jika tidak bisa biasanya RS akan meminta tumpangan dari tetangga atau kerabat yang memang melewati rumah sakit tempat anaknya dirawat.

Pada ME strategi coping yang dilakukan dipengaruhi oleh faktor dukungan sosial yang meliputi dukungan emosional dan informasi dari orang yang dikasihi, dan faktor materi yang meliputi sumber daya uang dan barang. ME disini mendapat dukungan penuh dari keluarag, keluarga ME juga mau berbagi peran untuk menjaga dan merawat anak ME ketika ME bekerja, selain itu karena kondisi keuangan ME yang cukup mendukung, ME mampu memisahkan ruang rawat inap anaknya dengan anak-anak lain.

Pada DM strategi coping dipengaruhi oleh faktor dukungan sosial dan faktor materi yang meliputi sumber daya uang dan barang, DM mendapatkan dukungan sosial dari keluarga dan teman-temannya. Dukungan materil juga moril, ia dapatkan dari keluarga yaitu ayah dan ibunya di Lampung. Dukungan moril ia dapatkan juga dari teman-teman seperjuangan yang memiliki anak sakit ALL seperti dirinya. Selama di Jakarta merawat anaknya, DM hanya mengandalkan kiriman uang dari orang tuanya.

Pada NP strategi coping dipengaruhi oleh faktor kesehatan fisik, dukungan sosial, dan sumber daya. NP memiliki sakit diabetes yang membuatnya tak boleh terlalu lelah, karena jika demikian gula darah NP akan menjadi tinggi. Kemudian NP juga mendapatkan dukungan baik dari saudara dan teman satu kamarnya di rumah sakit, hal ini membuat NP merasa lebih baik walau harus merawat anak sendiri tanpa bantuan suaminya, karena suami NP berada di luar negeri.

Menurut Taylor (2012) individu yang mendapatkan dukungan sosial akan mengalami stress lebih sedikit saat mereka menghadapi pengalaman yang stressful dan dapat melakukan coping dengan lebih baik. Bentuk dukungan sosial dapat berupa tangible assistance atau dukungan langsung yang melibatkan dukungan material seperti pelayanan, bantuan keuangan atau barang. Selain itu ada pula emotional support (dukungan emosional) yaitu dengan memberikan semangat, kehangatan dan pengasuhan yang diberikan oleh orang lain dapat memungkinkan seseorang tidak terlalu stres dan informational support (dukungan informasi) yaitu dengan menjelaskan situasi apa yang akan dihadapi, bagaimana menghadapinya, dan berapa lama waktu yang dibutuhkan. Dari penelitian ini diketahui seluruh subjek mencari dukungan sosial baik secara materil dan moril dari keluarga, tetangga dan yayasan yang menangani anakanak dengan penyakit kanker. Dukungan materil berbentuk tangible assistance yaitu bantuan dana atau pinjaman uang dari keluarga maupun tetangga untuk melakukan pengobatan anaknya. Dukungan moril berbentuk emotional dan informational support yang berupa nasihat-nasihat yang menjadi penyemangat dalam merawat anak, informasi seputar cara merawat anak, dukungan secara emosional yang berasal dari teman-teman yang memiliki anak dengan ALL, keluarga, paramedis, dan yayasan. 
Pada penelitian Mc Crae (Parkes, 1986, dalam Aziz, 2005) diketahui bahwa jika individu berada dalam situasi yang dinilai mengancam, maka individu akan kembali pada kepercayaan atau agama yang dianut dan melakukan sesuatu agar keinginan cepat dipenuhi oleh Tuhan. Hal ini dialami seluruh subjek dengan lebih berserah diri kepada Tuhan, beribadah, beryukur dan menganggap bahwa masalah yang dihadapi ini adalah cobaan dari Tuhan untuk menaikkan derajatnya atau menebus dosa di masa lalu. Lainnya yaitu mereka mendekatkan diri kepada Tuhan, ada subjek yang selalu ingin selalu bersedekah jika diberi rezeki oleh Tuhan. Hal ini dilakukan agar Tuhan mengabulkan doa mereka untuk menyembuhkan anaknya disamping mereka juga terus berusaha mendapatkan pengobatan bagi anaknya yang sakit. Hal ini didukung juga oleh penelitian Hashemi, et, al (2007) yang menemukan bahwa spiritual merupakan strategi paling banyak digunakan orang tua dalam merawat anaknya yang memiliki penyakit kanker.

\section{SIMPULAN DAN SARAN}

Berdasarkan hasil penelitian yang dilakukan dengan wawancara bersama lima orang tua yang memiliki anak dengan leukemia limfositik akut (ALL) diketahui pada subjek $\mathrm{S}$ dan RS, sumber stres berasal dari keluarga yaitu sakit yang diderita anak. Sementara pada ME, sumber stres berasal dari keluarga yaitu sakit yang diderita anak dan lingkungan yang menyudutkannya. Pada DM dan NP sumber stres berasal dari keluarga yaitu sakit yang diderita anak, diri sendiri, dan lingkungan.

Seluruh subjek S, RS, ME, DM, dan NP menggunakkan problem focused coping antara lain planful problem solving, seeking social support dan confrontative coping. Seluruh subjek juga menggunakan emotion focused coping. Seluruh subjek S, RS, ME, DM, dan NP menggunakkan self control, accepting responsibility, dan positive reappraisal. Hanya subjek RS, ME, NP yang menggunakan distancing.

Dari penelitian ini dihasilkan saran bagi penelitian selanjutnya yaitu jika $g$ ingin meneliti tentang coping stres pada orang tua dengan anak ALL dapat memberikan pertanyaan dengan kalimat yang lebih sederhana supaya mudah dipahami, dapat juga mewawancarai pasangan orang tua, supaya data yang diperoleh berasal dari dua sisi orang tua, ayah dan ibu, karena penelitian ini hanya mewawancarai salah satu dari orang tua anak.

Kemudian saran untuk orang tua anak dengan ALL adalah dapat melakukan kegiatan positif yang sekiranya dapat meringankan beban pikiran sejenak, dengan melakukan hobi bersama dengan anak jika kondisi anak memungkinkan. Selain itu juga agar selalu mendekatkan diri pada Tuhan supaya bisa bertahan dalam menghadapi masalah selama merawat anak dengan cara berdoa bersama dengan anak. Penting juga mencari atau bergabung dengan komunitas orang tua yang memiliki anak pengidap ALL agar dapat saling bertukar informasi dan saling mendukung juga menguatkan satu sama lain.

Saran untuk kerabat terdekat orang tua anak dengan ALL agar selalu memberi dukungan moril seperti semangat, informasi yang dibutuhkan, dan menjadi tempat berkeluh kesah orang tua yang sedang merawat anak ALL, karena dukungan moril sangat berdampak bagi psikologis orang tua. Saran untuk rumah sakit yang menaungi pengobatan kanker bagi anak-anak adalah agar melakukan kerja sama dengan yayasan kanker yang tersedia untuk membuka layanan pengaduan 24 jam yang dapat menjawab pertanyaan seputar informasi penyakit anak yang di derita, selain itu menyediakan kelompok pendamping bagi orang tua yang memiliki anak dengan ALL agar dapat saling bertukar informasi. Karena sampai penelitian ini selesai, sosialisasi mengenai bahaya, pencegahan, dan penaganan untuk anak kanker masih belum diketahui secara baik oleh orang tua.

\section{DAFTAR PUSTAKA}

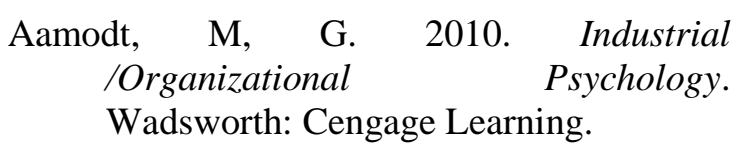

Baumgardner, S, R., \& Crothers, M, K. 2009. Positive Psychology. Pearson Prentice Hall.

Boyer, B, A., \& Paharia, M, I. 2008. Comprehensive Handbook of Clinical Health Psychology. Canada: John Wiley and Sons. 
Brannon, L., Feist, J., Updegraff, J, A. 2014. Health Psychology an Introduction to Behavior and Health. Wadsworth Cengage Learning

Carter, D, C. 2004. Quantitative Psychological Research. Psychology Press

Gilmartin, J. 2009. Health Psychology in Context. United Kingdom: WileyBlackwell

Gunawan, I. 2013. Metode Penelitian Kualitatif. Bumi Aksara.

Kring, A., Johnson, S., Davison, G, C., \& Neale, J, M. 2010. Abnormal Psychology $11^{\text {th }}$ ed. United States: Wiley.

Lyons, E., Coyle, A. 2008. Analysing Qualitative Data in Psychology. Sage.

Mack, N., Woodsong, C., Macqueen, K,M., Guest, G., Namey, E. 2005. Qualitative Research Methods: A Data Collector's Field Guide. Fhi360. Usaid.

Ogden, J. 2007. Health Psychology A Text Book Fourth Edition. Mc Graw Hill.

Olpin, M., \& Hesson, M. 2013. Stress Management for Life: A ResearchBased, Experiential Approach International Edition. Wadsworth: Cengage Learning.

Poerwandari, E, K. 2011. Pendekatan Kualitatif untuk Penelitian Perilaku Manusia. Fakultas Psikologi Universitas Indonesia.

Sarafino, E, P., \& Smith, T, W. 2012. Health Psychology Biopsychosocial Interactions. John Wiley and Sons.

Stern, T, A., \& Sekeres, M, A. 2004. Facing Cancer: A complete Guide for People with Cancer, Their Families, and Caregivers. United States: Mc-Graw Hill

Taylor, S, E. 2006. Health Psychology. McGraw Hill.
Vandenbos, G. 2007. APA Dictionary of Psychology. United States: American Psychological Association.

\section{$\underline{\text { Jurnal }}$}

Andriyani, J. (2014). Coping Stress Pada Wanita Karier yang Berkeluarga. Jurnal Al-Bayan, 20, No. 30, Juli-Desember 2014. Universitas Islam Negeri ArRaniry Banda Aceh

Aziz, M, F., Kumolohadi, R. (2005). Strategi Pengatasan Masalah Pada Orang Tua Pasien Leukemia. Fakultas Psikologi Universitas Islam Indonesia Yogyakarta. https://psychology.uii.ac.id./naskahpublikasi-01320076.

Cahyono, A. (2012). Gambaran Tindakan Orang Tua Yang Mempunyai Anak Dengan Penderita Leukemia Di Ruang Melati Ii Rsud Dr. Moewardi. Fakultas Ilmu Kesehatan Universitas Muhammadiyah Surakarta. https://eprints.ums.ac.id/22699/18/13._ Naskah_publikasi.pdf

Given, B., Wyatt, G., Given, C., Gift, A., Sheerwood, P., DeVoss, D., \& Rahbar, M. (2005). Burden and Depression Among Caregivers of Patients with Cancer at the End-of-life. NIH Public Access, 31(6), 1105-1117

Hashemi, F., Razavi, Sh., Sharif, F., \& Shahriari, MM. (2007). Coping Strategies Used By Parents's Of Children With Cancer In Shiraz, Southern Iran. Iranian Red Crescent Society volume 9, No. 3, 124-128

Maria, A., Indriati, G., \& Rahmalia, S. (2014). Pengalaman Ibu Dalam Merawat Anak Dengan Leukemia. http://jom.unri.ac.id/index.php/JOMPSI $\underline{\text { K/article/viewFile/3520/3415 }}$

Mayring, P. (2009). Qualitative Content Analysis. Forum Qualitative Social Research, vol 1 no 2. http://nbnresolving.de/urn:nbn:de:0114fqs0002204. 
Pinontoan, E., Mantik, M., \& Rampengan, N. (2013). Pengaruh Kemoterapi Terhadap Profil Hematologi Pada Penderita Leukemia Limfoblastik Akut. Jurnal Ilmu Kesehatan Anak FK UNSRAT Manado, vol 1, no2. http://ejournal.unsrat.ac.id/index.php/ecl inic/article/view/3277

Puspita, S,K., Ludiro, S, K. (2013). Kondisi Orang Tua Pasien Kanker Anak Dilihat Dari Aspek Biopsikososial Berdasarkan Fase Pengobatan Anak (Studi Deskiptif Pada Support Group Sebagai Program Dalam Komunitas Pita Emas Rumah Sakit Kanker Dharmais Jakarta).FISIP UI.

http://lib.ui.ac.id/naskahringkas/201509/S47545-Sisca\%20Kezia\%20Puspita

Rani, M, V, I., Dundu, A, E., Kaunang, T, M, D. (2015). Gambaran Tingkat Kecemasan Pada Ibu Yang Anaknya Menderita Leukemia Limfoblastik Akut Di Rsup Prof. Dr. R. D. Kandou Manado. Jurnal e-Clinic (eCl), Volume 3, Nomor 1, Januari-April 2015. http://ejournal.unsrat.ac.id/index.php/ecl inic/article/download/7401/6944

Rizkiana, U. (2012). Penerimaan Diri Pada Remaja Penderita Leukemia. E-Journal Gunadarma Vol 2 no 2 http://ejournal.gunadarma.ac.id/index.ph p/psiko/article/view/412

Rustiana, E.R., Cahyati, W.H. (2012). Stress Kerja Dengan Pemilihan Strategi Coping. KEMAS 7 (2) (2012) 149-155

Simanjorang, C., Kodim, N., \& Tehuter, E. (2013). Perbedaan Kesintasan 5 Tahun Pasien Leukemia Limfoblastik Akut Dan Leukemia Mieloblastik Akut Pada Anak Di Rumah Sakit Kanker "Dharmais" Jakarta, 1997-2008. Indonesian Journal Of Cancer Vol. 7, No. 1. http://www.indonesianjournalofcancer.o r.id/ejournal/index.php/ijoc/article/view/274/ $\underline{145}$

Tehuteru, E.S. (2011). Gambaran Tingkat Remisi pada Leukemia Limfoblastik
Akut setelah Fase Induksi di Bangsal Kanker Anak RS Kanker Dharmais. Indonesian Journal of Cancer Vol. 5, No. $4,159-162$

Suryati., Rustina, Y., Nurhaeni, N. (2015). Hubungan Koping Orang Tua Dan Karakteristik Anak Dengan Pertumbuhan Dan Perkembangan Penderita Leukemia Limfositik Akut Usia Batita Dan Prasekolah Di Rsab Harapan Kita Jakarta. Repository University of Riau. http://repository.unri.ac.id/xmlui/handle/123 $\underline{456789 / 7457}$

\section{$\underline{\text { E-Resources }}$}

Manafe, D. 2014. 62\% Kanker Anak Ditemukan pada Stadium Lanjut. http://www.beritasatu.com/kesehatan/16 6445-62-kanker-anak-ditemukan-padastadium-lanjut.html diakses tanggal 3 Februari 2016

NN. Apa itu kanker. www.parkwaycancercentre.com/id/infor masi-kanker/tentang-kanker/apa-itukanker/ diakses tanggal 9 September 2015

NN. 2012. 4\% Penderita Kanker adalah Anakanak.

http://www.pdpersi.co.id/content/news.p hp? catid $=23 \&$ mid $=5 \&$ nid $=718$

diakses tanggal 31 Agustus 2015

Noel, F. 2015. Kanker Mata, Penyebab Kematian Tertinggi Kedua! Kenali Gejalanya.

http://manado.tribunnews.com/2015/04/ 16/kanker-mata-penyebab-kematiantertinggi-kedua-kenali-gejalanya diakses tanggal 31 Agustus 2015

Pramudiarja, AN, U. 2011. Ini dia Negara dengan Penderita Kanker Terbanyak. http://health.detik.com/read/2011/01/25/ 083359/1553758/763/ini-dia-negaradengan-penderita-kanker-terbanyak diakses tanggal 31 Agustus 2015

Straus, D. (2009). Relapsed and Refractory Hodgkin Lymphoma. Lymphoma Research Foundation: New York. http://www.lymphoma.org/atf/cf/\%7BA 
AF3B4E5-2C43-404C-AFE5FD903C87B254\%7D/HLBOOK09.PDF diakses 2 April 2016

Ugrahsena, I.D.G. 2012. Leukemia Pada Anak. http://www.pdpersi.co.id/content/article. php?mid=\&catid=9\&nid=712 . Di akses Tanggal 31 Agustus 2015
Wulandari, S. 2014. Cerita Perjuangan Seorang Ibu Merawat Anaknya yang Menderita Leukemia. http://family.fimela.com/anak/kuatsehat/cerita-perjuangan-seorang-ibumerawat-anaknya-yang-menderita-

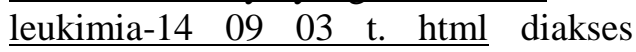
\begin{tabular}{llll}
\hline tanggal & 31 & Agustu
\end{tabular} 
